\title{
Isolation, Quality Evaluation, and Seasonal Changes of Bakkenolide B in Petasites japonicus by HPLC
}

\author{
Tae Hoon Kim ${ }^{1}$, Do Youn Kim¹, Won Jung Jung ${ }^{1}$, Ravichandran Nagaiya ${ }^{1}$, Beung Gu Son ${ }^{1}$, Young Hoon \\ Park ${ }^{1}$, Jum Soon Kang ${ }^{1}$, Young Jae Lee ${ }^{1}$, Dong-Soon $\mathrm{Im}^{2}$, Young-Geun Lee ${ }^{3}$, Yung Hyun $\mathrm{Choi}^{4}$ and \\ Young-Whan $\mathrm{Choi}^{1 *}$
}

\author{
${ }^{1}$ Department of Horticultural Bioscience, Pusan National University, Miryang 627-706, Korea \\ ${ }^{2}$ Department of Pharmaceutics, Pusan National University, Busan 609-735, Korea \\ ${ }^{3}$ Department of Food Science and Technology, Pusan National University, Miryang 627-706, Korea \\ ${ }^{4}$ Department of Biochemistry, College of Oriental Medicine, Dongeui University, Busan 609-734, Korea
}

Received December 17, 2013 /Revised March 14, 2014 / Accepted March 18, 2014

\begin{abstract}
The leaves of Peatasites japonicus are a traditional oriental medicine with diverse biological activities. A simple and specific analytical method for the quantitative determination of bakkenolide B constituents from methanolic extract of the leaves of $P$. japonicus was developed. Bakkenolide B was isolated from the leaves of $P$. japonicus, and its structure was elucidated based on 1D, 2D NMR, and GC-MS spectral data. A liquid chromatographic method was developed to evaluate the quality of $P$. japonicus through determination of major active compound, bakkenolide B. The wavelengths at 254 and $215 \mathrm{~nm}$ were chosen to determine bakkenolide B. The recovery of the method was in the range of 98.6 to $103.1 \%$, and bakkenolide B showed good linearity $\left(r^{2}=0.999\right)$ within test ranges. The developed method was applied to the determination of bakkenolide B in the plant part and seasonal changes. The results showed that the content of bakkenolide B in the leaf was higher than in the petiole and rhizome. In this study, a simple, rapid, and reliable high-performance liquid chromatography method was used to determine the percentage and composition of bakkenolide B in $P$. japonicus procured from different Petasites species plants in South Korea. The method can be employed in routine quantitative analysis and quality control of different products in the market.
\end{abstract}

Key words : Bakkenolide B, HPLC, Petasites japonicus, quality evaluation, seasonal change

\section{Introduction}

Petasites japonicus (Sieb. et Zucc.) Maxim, is a perennial herbaceous, belonging to the family Compositae, distributed in Korea, Japan and East China. It has been consumed as a wild leafy vegetable in recent years $[14,16]$. $P$. japonicus has been utilized as a folk medicine for the treatment of furunculosis, contusion, wounds, and snakebites [10]. Previous phytochemical investigations on $P$. japonicus contained the main presence of sesquiterpenoids, especially eremophilane-type sesquiterpenoids [9, 15, 17, 22, 23, 24]. In our survey process on biologically active substances in medicinal plants, considerable attention has been given to the

\footnotetext{
*Corresponding author

Tel : +82-55-350-5522, Fax : +82-055-350-5529

E-mail : ywchoi@pusan.ac.kr

This is an Open-Access article distributed under the terms of the Creative Commons Attribution Non-Commercial License (http://creativecommons.org/licenses/by-nc/3.0) which permits unrestricted non-commercial use, distribution, and reproduction in any medium, provided the original work is properly cited
}

occurrence of compounds with anti-inflammatory, anticancer, and neuroprotective effects $[7,9,12,13]$, since these substances are expected to be potentially useful for the treatment and prevention of Parkinson's diseases [5]. As a continuation of our work on the search for bioactive substances from traditional folk medicines or medicinal food [7, 12, 13], we reported on the structural elucidation of sesquiterpene lactones from the leaf of $P$. japonicus, and confirmed that the bakkenolide $B$ exhibited significant anti-allertic activity [9]. Bakkenolide-B is the major sesquiterpene lactones in $P$. japonicus and can be utilized to evaluate their quality. The distribution of the medicinal constituents plays an important role in raw material selection for medical extract production. However, there is no report about analytical methods for the seasonal changes and plant parts of bakkenolide B in $P$. japonicus. There is a great interest in establishing an analytical method for the quality control of $P$. japonicus for better applications in the medicinal herb industry. Therefore, we focused our investigations on the isolation and characterization of bakkenolide B, and its contents in different seasons 
and parts of $P$. japonicus were compared to establish the effectiveness of the method.

\section{Materials and Methods}

\section{Materials}

$P$. japonicus were planted at the Agricultural Experimental Field (Miryang, Gyeongnam) of Pusan National University in November, 2012 and leaves, petioles and rhizomes collected with one month interval from March to August, 2013. These samples were stored at $-20^{\circ} \mathrm{C}$ prior to testing. A voucher specimen (accession number MW-PRDR-11) was deposited at the Herbarium of Pusan National University. HPLC-grade water and acetonitrile were purchased from Fisher (Fair Lawn, NJ, USA). Distilled water was produced from Milli-pore water purified system. All the solutions were degassed by an ultrasonic bath before use. Bakkenolide $\mathrm{B}$ was extracted and purified from the leaves of $P$. japanicus with minimum purity of $98.0 \%$ by GC-MS (Gas chromatography - mass spectrometry). The chemical structure of bakkenolide B was identified by spectral method $\left({ }^{1} \mathrm{H} \mathrm{NMR},{ }^{13} \mathrm{C}\right.$ NMR, 2D NMR and MS) and confirmed by comparing with those in literature [1]. The ${ }^{1} \mathrm{H}-\mathrm{NMR},{ }^{13} \mathrm{C}-\mathrm{NMR}$, and 2D-NMR spectra were recorded on a Bruker DMX-500NMR spectrometer (Bruker, Billerica, Massachusetts, USA) using TMS as an internal standard. Silica gel (60-200 mesh) (Merk, Darmstadt, Germany) was used for column chromatography.

\section{Isolation of bakkenolide B}

The fresh leaves of $P$. japonicus $(1.0 \mathrm{~kg})$ were chopped to fine particles with an electric mixer (HMF-3100 S, Hanil Electric, Seoul, Korea) and then extracted with $70 \%$ ethanol $(31 \times 3)$ under sonicator for one hour at room temperature (Fig. 1). The solvent was evaporated under reduced pressure to obtain EtOH extracts. This residue was suspended in $\mathrm{H}_{2} \mathrm{O}(500 \mathrm{ml})$ and successively partitioned with hexane $(11 \times 3)$, ethyl acetate $(11 \times 3), \mathrm{BuOH}(500 \mathrm{ml} \times 3)$ and aqueous extract. The hexane extract $(2.673 \mathrm{~g})$ from total hexane extract $(13.60 \mathrm{~g})$ was evaporated in vacuo, and then chromatographed on a silica gel (40 $\mu \mathrm{m}$, Baker, NJ) column $(100 \times 4.0 \mathrm{~cm})$ using a step gradient $2.5 \%, 15 \%, 25 \%$ acetone in dichloromethylene and $15 \%$ and $25 \% \mathrm{MeOH}$ in chloroform to obtain 62 fractions. Fraction 9 (MWLSH9, $304.9 \mathrm{mg}$ ) was separated on a Sephadex column $(100 \times 3.0 \mathrm{~cm})$ using $\mathrm{MeOH}$ as eluant to obtain 7 fractions. The fraction 3 (MWLSH9IC, $209.7 \mathrm{mg}$ ) was further separated on a Sephadex column $(100 \times 3.0 \mathrm{~cm})$ using $\mathrm{MeOH}$ to obtain five fractions. Fractions 2 and 3 (MWLSH9ICIB, $202.3 \mathrm{mg}$ ) were passed through a silica gel column $(100 \times 4.0 \mathrm{~cm})$ using $1.5 \%$ acetone in $\mathrm{CH}_{2} \mathrm{Cl}_{2}$ as eluant to yield bakkenolide $\mathrm{B}$ (173.8 $\mathrm{mg}$ ). Pure bakkenolide B was identified by HPLC on a Phenomenex Luna $C_{18}$ column (Phenomenex, 150×4.6 mm ID; $5 \mu \mathrm{m}$ particle size, Phenomenex, Torrance, CA, USA) using an acetonitrile-water gradient at a flow rate of $0.4 \mathrm{ml}$ per minute. Bakkenolide $\mathrm{B}$ isolated from $P$. japonicus leaves was identified using ${ }^{1} \mathrm{H},{ }^{13} \mathrm{C}$, and Dept (distortionless enhancement of polarization transfer) nuclear magnetic resonance spectroscopy in $\mathrm{CDCl}_{3}$ by comparison with previously reported spectral data $[6,11]$.

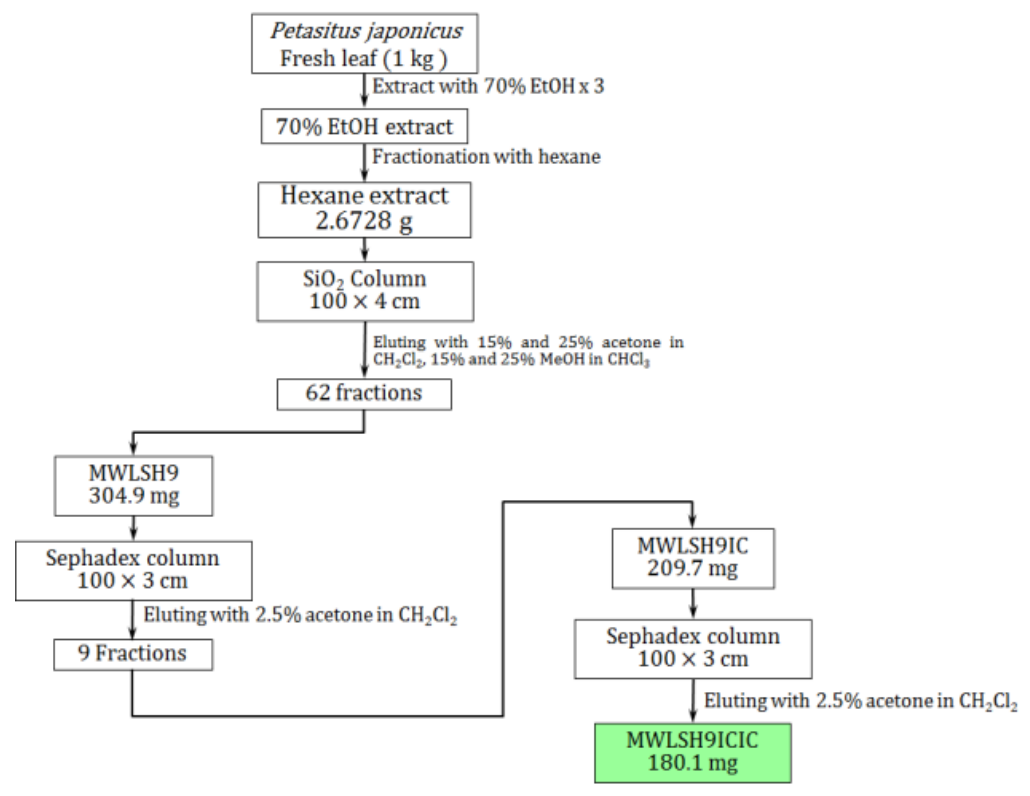

Fig. 1. Isolation scheme of bakkenolide B from leaves of Petasitus japonicus. The fresh leaves of $P$. japanicus $(1.0 \mathrm{~kg})$ were chopped to a fine particle with an electric mixer and then extracted with $70 \%$ ethanol $(31 \times 3)$ under sonicator for one hour at room temperature. The hexane extract was chromatographed on a silica gel column using a step gradient $2.5 \%, 15 \%, 25 \%$ acetone in dichloromethylene and $15 \%$ and $25 \%$ $\mathrm{MeOH}$ in chloroform to obtain 62 fractions. Fraction 9 was successively separated on a Sephadex and normal silica column to yield bakkenolide B (173.8 mg). 


\section{Sample preparation}

All samples (including leaves, petioles and rhizomes) were stored at $-20^{\circ} \mathrm{C}$ for use. A sample of $1 \mathrm{~g}$ fresh weight was mixed by using mortar and pestle and sonicated in $5 \mathrm{ml} \mathrm{MeOH}$ for $60 \mathrm{~min}$ three times. The extract was centrifuged at 3,000 rpm for $10 \mathrm{~min}$ and collected supernatant was then adjust to $15 \mathrm{ml}$ with $\mathrm{MeOH}$. The sample solution was filtered through a 0.45 $\mu \mathrm{m}$ membrane before HPLC (performance liquid chromatography) analysis.

\section{Analytical method}

Chromatographic analyses were performed on Agilent Technologies (Waldbronn, Germany) G1100 systems equipped with a vacuum degasser, quaternary pump, thermostated oven device and a variable wavelength UV detector. The chromatographic data were acquired and analyzed using Agilent chromatographic Work Station software. Analyses were carried out on a Luna $\mathrm{C}_{18}$ column $(5 \mu \mathrm{m}$, $150 \times 3.0 \mathrm{~mm}$ i.d. Phenomenex, Torrance, CA, USA) with a mobile phase gradient of acetonitrile - water (0 to 100) for $35 \mathrm{~min}$. The injection volume was $10 \mu \mathrm{l}$ sample. The column temperature was kept constant at $30^{\circ} \mathrm{C}$, and the mobile phase flow rate was $0.4 \mathrm{ml} \mathrm{min}^{-1}$ with UV detection at 210, 215, 235, $254 \mathrm{~nm}$ and $360 \mathrm{~nm}$.

\section{Calibration curves, limits of detection and quantification}

Stock solution of bakkenolide B was prepared by solving $2.0 \mathrm{mg}$ bakkenolide $\mathrm{B}$ to $2 \mathrm{ml}$ methanol. The concentration of bakkenolide B was $1.0 \mathrm{mg} \mathrm{ml}^{-1}$. The stock solution was further diluted to make different concentration ranges. The calibration curve was performed with at least five appropriate concentrations in triplicate. These concentrations were appropriate for the calibration curves: 500, 250, 125, 62.5 and $31.25 \mathrm{mg} / \mathrm{ml}$ of the original concentration. The solutions were brought to room temperature and filtered through a $0.45 \mu \mathrm{m}$ membrane filter and an aliquot of $10 \mu \mathrm{l}$ was injected into the HPLC for analysis. Their regression equations were calculated in the form of $y=a x+b$, where $x$ and $y$ were peak area and contents of compound, respectively. The diluted solution of bakkenolide B was further diluted to a series of concentrations with methanol for gaining the limits of detection (LOD) and quantification (LOQ). The LOD and LOQ under the present chromatographic conditions were determined at a signal-to-noise ratio of 3 and 10, respectively.

\section{Precision, repeatability and accuracy}

The intra- and inter-day precision was determined by ana- lyzing calibration samples during a single day on three different days. To confirm the repeatability, three different working solutions were prepared from the leaves sample. The RSD (relative standard deviation) was taken as a measure of precision and repeatability. Recovery test was used to evaluate the accuracy of this method by adding $50 \mu \mathrm{g}$ bakkenolide $\mathrm{B}$ to approximately $1 \mathrm{~g}$ of fresh leave extract of $P$. japonicus. The average recoveries were counted by the formula: recovery $(\%)=($ amount found-original amount)/amount spiked $\times 100 \%$, and RSD (\%)=(standard deviation/ mean) $\times 100 \%$.

\section{Results}

\section{Extraction and isolation of bakkenolide $B$}

The hexane extract $(2.673 \mathrm{~g})$ from total hexane extract $(13.60 \mathrm{~g})$ was subjected to column chromatography packed with silica gel and gradiently eluted with mixed 15, 25 acetone in $\mathrm{CH}_{2} \mathrm{Cl}_{2}, 15 \%$ and $25 \%$ in $\mathrm{CHCl}_{3}$ to give 62 fractions. Fraction 9 (MWLSH $304.9 \mathrm{mg}$ ) was chromatographed on a sephadex $(100 \times 3.0 \mathrm{~cm})$ further fractionated using a $2.5 \%$ acetone in $\mathrm{CH}_{2} \mathrm{Cl}_{2}$ to yield pure compound $180.1 \mathrm{mg}$ (MWLSH9ICIC). GC-MS data suggested that the purity of the compound was more than $97 \%$.

\section{Structure elucidation of bakkenolide B}

In the course of our survey on pharmacologically active substances in medicinal plants $[7,12,13]$, much attention has been given to the occurrence of compounds with anti-allergic effects, since these compounds are expected to be potentially useful for the treatment and prevention of Parkinson's disease. We investigated the chemical constituents of the leaves of $P$. japonicus, of which the hexane extract showed moderate anti-allergic effects [9]. As a result of further chemical investigation for bioactive products, bakkenolide $\mathrm{B}$ were isolated from the leaves of $P$. japonicus. Herein, we describe the isolation and structural elucidation of bakkenolide B (Table 1. and Fig. 2).

Molecular formula of Bakkenolide B (BB), $\mathrm{C}_{22} \mathrm{H}_{30} \mathrm{O}_{6}$, was determined by GC-MS ( $\mathrm{m} / \mathrm{z} 390$ for $\left.\mathrm{C}_{22} \mathrm{H}_{30} \mathrm{O}_{6}\right)$. The ${ }^{1} \mathrm{H}$ NMR data (Table 1) for BB exhibited five methyl groups at $\delta 0.82$ $(3 \mathrm{H}, \mathrm{d}, \mathrm{J}=6.5 \mathrm{~Hz}, \mathrm{H}-14), 1.03$ (3H, s, H-15), 1.84 (3H, s, $\left.-\mathrm{COCH}_{3}, \mathrm{H}-2^{\prime \prime}\right), 1.70\left(3 \mathrm{H}, \mathrm{s},-\mathrm{COC}\left(\mathrm{CH}_{3}\right)=\mathrm{CHCH}_{3}, \mathrm{H}-5\right)$, and $1.79\left(1.79, \mathrm{~d}, \mathrm{~J}=6.5 \mathrm{~Hz},-\mathrm{COC}\left(\mathrm{CH}_{3}\right)=\mathrm{CHCH}_{3}, \mathrm{H}-4\right)$, two olefinic protons at $\delta 5.10(2 \mathrm{H}, \mathrm{s}, \mathrm{H}-13)$, two oxygenated methines at $\delta 5.09(1 \mathrm{H}, \mathrm{br}, \mathrm{H}-1)$ and $5.66(1 \mathrm{H}, \mathrm{d}, \mathrm{J}=11.0 \mathrm{~Hz}$, 
Table $1 .{ }^{1} \mathrm{H}$ and ${ }^{13} \mathrm{C}$ NMR spectroscopic data of bakkenolide B $\left({ }^{1} \mathrm{H}\right.$ NMR $500 \mathrm{MHz},{ }^{13} \mathrm{C}$ NMR $125 \mathrm{MHz}$ in $\left.\mathrm{CDCl}_{3}\right)$

\begin{tabular}{|c|c|c|c|c|}
\hline Position & & & $\delta_{\mathrm{H}}$ & $\mathrm{HMBC}$ \\
\hline 1 & 70.40 & $\mathrm{CH}$ & $5.09, \mathrm{~s}$ & \\
\hline 2 & 26.77 & $\mathrm{CH}_{2}$ & $1.73, \mathrm{dd}, \mathrm{J}=9.5 / 6.5$ & \\
\hline 3 & 29.50 & $\mathrm{CH}_{2}$ & $1.63, \mathrm{br}$ & \\
\hline 4 & 35.22 & $\mathrm{CH}$ & $1.56, \mathrm{br}$ & \\
\hline 5 & 43.28 & $\mathrm{C}$ & & \\
\hline 6 & 45.81 & $\mathrm{CH}_{2}$ & $\begin{array}{l}2.14, \mathrm{~d}, \mathrm{~J}=14.0 \\
1.87, \mathrm{~d}, \mathrm{~J}=14.0\end{array}$ & $177.38,147.75,54.91,43.28,35.22,19.53$ \\
\hline 7 & 54.91 & $\mathrm{C}$ & & \\
\hline 8 & 177.38 & $\mathrm{C}$ & & \\
\hline 9 & 80.75 & $\mathrm{CH}$ & $5.66, d, J=11.0$ & $177.38,169.81,147.75,70.40$ \\
\hline 10 & 51.41 & $\mathrm{CH}$ & $2.72, \mathrm{br}$ & $80.75,70.40,43.28,35.22,26.77,19.53$ \\
\hline 11 & 147.75 & $\mathrm{C}$ & & \\
\hline 12 & 70.52 & $\mathrm{CH}_{2}$ & $4.57, \mathrm{t}$ & \\
\hline 13 & 108.22 & $\mathrm{CH}_{2}$ & $5.10, \mathrm{~d}, \mathrm{~J}=14.0$ & $70.52,54.91$ \\
\hline 14 & 15.48 & $\mathrm{CH}_{3}$ & $0.82, \mathrm{~d}, \mathrm{~J}=6.5$ & $43.28,35.22,29.50$ \\
\hline 15 & 19.53 & $\mathrm{CH}_{3}$ & $1.03, \mathrm{~s}$ & $51.41,45.81,43.28,35.22$ \\
\hline $1^{\prime}$ & 167.17 & $\mathrm{C}$ & & \\
\hline $2^{\prime}$ & 128.20 & $\mathrm{C}$ & & \\
\hline $3^{\prime}$ & 136.58 & $\mathrm{CH}$ & $5.86, \mathrm{~d}, \mathrm{~d}$ & \\
\hline $4^{\prime}$ & 15.48 & $\mathrm{CH}_{3}$ & $1.79, \mathrm{~d}, \mathrm{~J}=6.5$ & $136.58,128.20$ \\
\hline $5^{\prime}$ & 20.29 & $\mathrm{CH}_{3}$ & $1.70, \mathrm{~s}$ & $167.17,136.58,128.20,20.90$ \\
\hline $1^{\prime \prime}$ & 169.81 & $\mathrm{C}$ & & \\
\hline $2^{\prime \prime}$ & 20.90 & $\mathrm{CH}_{3}$ & $1.84, \mathrm{~s}$ & 169.81 \\
\hline
\end{tabular}

*Assignments of chemical shifts of bakkenolide B was confirmed by DEPT, gHMQC, gHMBC

A

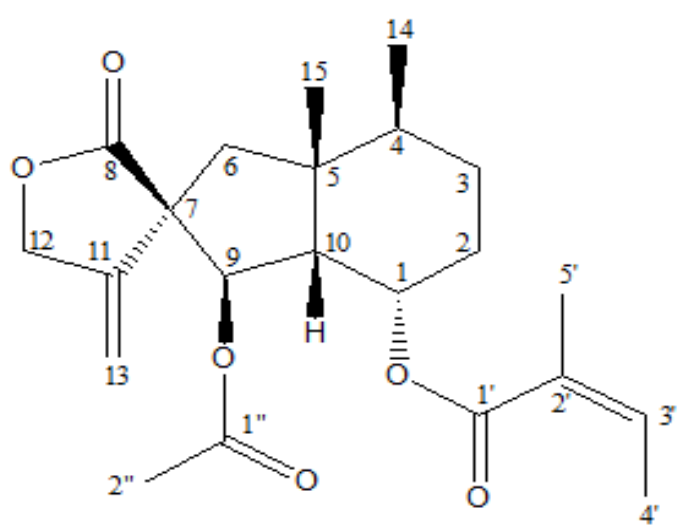

B

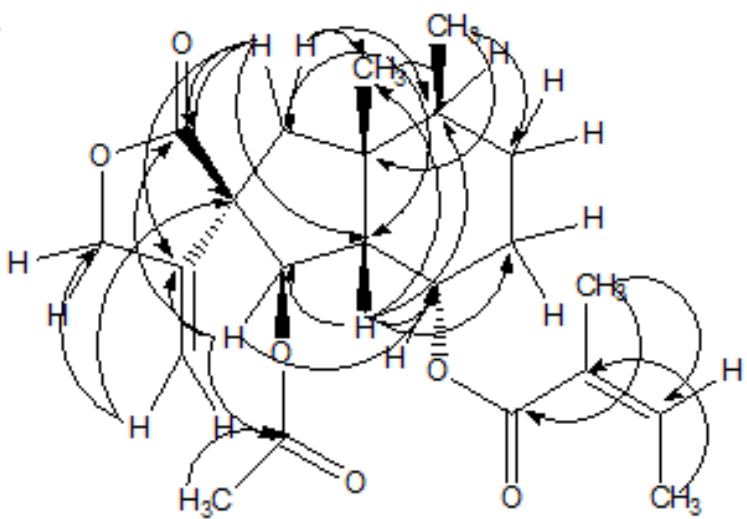

Fig. 2. Structure (A) and key HMBC (B) of bakkenolide B.

$\mathrm{H}-9)$, and an oxygenated methylene at $\delta 4.57(2 \mathrm{H}, \mathrm{t}, \mathrm{H}-12)$. Bakkenolide $\mathrm{B}$ was determined to be optically active and to contain a bakkenolide-type skeleton with two substituents on C-1 and C-9 based on their ${ }^{1} \mathrm{H}-\mathrm{NMR}$ and ${ }^{13} \mathrm{C}-\mathrm{NMR}$ spectra (Table 1) and by comparison with previously reported data $[1,21]$ and completely assigned based on the two-dimensional (2D) NMR spectra. The ${ }^{13} \mathrm{C}$ NMR spectrum of bakkenolide $\mathrm{B}$, in combination with the DEPT and HMQC spectra, showed twenty two carbon signals that were classified into five methyls [ $\delta 15.48$ (C-14), 19.53 (C-15), 20.90
$\left(-\mathrm{COCH}_{3}, \mathrm{C}-2^{\prime \prime}\right), 15.48\left(-\mathrm{COC}\left(\mathrm{CH}_{3}\right)=\mathrm{CHCH} \mathrm{CH}_{3} \mathrm{C}-4^{\prime}\right)$, and 20.29 $\left.\left(-\mathrm{COC}\left(\mathrm{CH}_{3}\right)=\mathrm{CHCH}_{3}, \mathrm{C}-5^{\prime}\right)\right]$, five methylenes [ $\delta 26.77(\mathrm{C}-2)$, 29.50 (C-3), 45.81 (C-6), 70.52 (C-12), and 108.22 (C-13)], five methines [8 70.40 (C-1), 35.22 (C-4), 80.75 (C-9), 51.41 (C-10), and $\left.136.58\left(-\mathrm{COC}(\mathrm{CH} 3)=\mathrm{CHCH}_{3}, \mathrm{C}-3^{\prime}\right)\right]$, and seven quaternary carbons [ $\delta 43.28$ (C-5), 54.91 (C-7), 178.38 (C-8), 147.74 (C-11), $169.81(-\mathrm{COCH} 3, \mathrm{C}-1 "), 128.20(-\mathrm{COC} \mathrm{CH} 3)=\mathrm{CHCH}_{3}$, c), and $\left.167.17\left(-\mathrm{COC}\left(\mathrm{CH}_{3}\right)=\mathrm{CHCH}_{3}\right)\right]$. Close similarities of the chemical shifts from C-1 to C-15 for BB with reported values for similar compounds implied that 1 was a bakkeno- 
lide-type sesquiterpene with an acetoxy and an angeloyloxy $[1,18,21]$. The further analysis of HSQC and HMBC spectra confirmed the presence of the bakkenolide-type skeleton, the acetoxy, and the angeloyloxy groups. The HMBC correlations of H-9 to the carbonyl carbon of the acetoxy, and H-1 to the carbonyl carbon of the angeloyloxy, revealed that the acetoxy and the angeloyloxy were attached at C-1 and C-9, respectively. By analysing the $\mathrm{HSQC}, \mathrm{HMBC}$, and ${ }^{1} \mathrm{H}-{ }^{1} \mathrm{H}$ COSY spectra (Fig. 2), all the proton and carbon signals were assigned unambiguously. Thus, the planar structure of BB was disclosed.

\section{Analytical conditions}

HPLC conditions, especially the mobile phase and its elution program, are also of importance for the determination of the compound in the biological matrix. In this study, we found that a mobile phase consisting of acetonitrile and $\mathrm{H}_{2} \mathrm{O}$ can separate bakkenolide B (Fig. 3). The selection of the LC conditions was guided by the requirement for obtaining chromatograms with better resolution. The LC conditions developed in this study produced full peak-to-baseline resolution of the major active bakkenolide B present in $P$. japonicus sample. On the basis of UV maximal absorption of the bakkenolide B shown in Fig. 3, the choice of detection at $215 \mathrm{~nm}$ for quantitative analysis was appropriate.

\section{Validation of the method}

The analysis method for bakkenolide B was validated based on linear calibration curve with $\mathrm{r}^{2}$, linear range, -LOD and LOQ of bakkenolide B. As a result, calibration curve showed good linear regression $\left(\mathrm{r}^{2}=0.999\right)$ within test ranges; the LOD $(\mathrm{S} / \mathrm{N}=3)$ and the LOQ $(\mathrm{S} / \mathrm{N}=10)$ for the bakkenolide B were less than 1.05 and $3.38 \mu \mathrm{g}$ in $210 \mathrm{~nm}$ and 2.26 and $6.84 \mu \mathrm{g}$ in $254 \mathrm{~nm}$, respectively (Table 2).

Table 3 shows the results of precision of the bakkenolide B. It indicates that the RSD of the overall 215 and $254 \mathrm{~nm}$

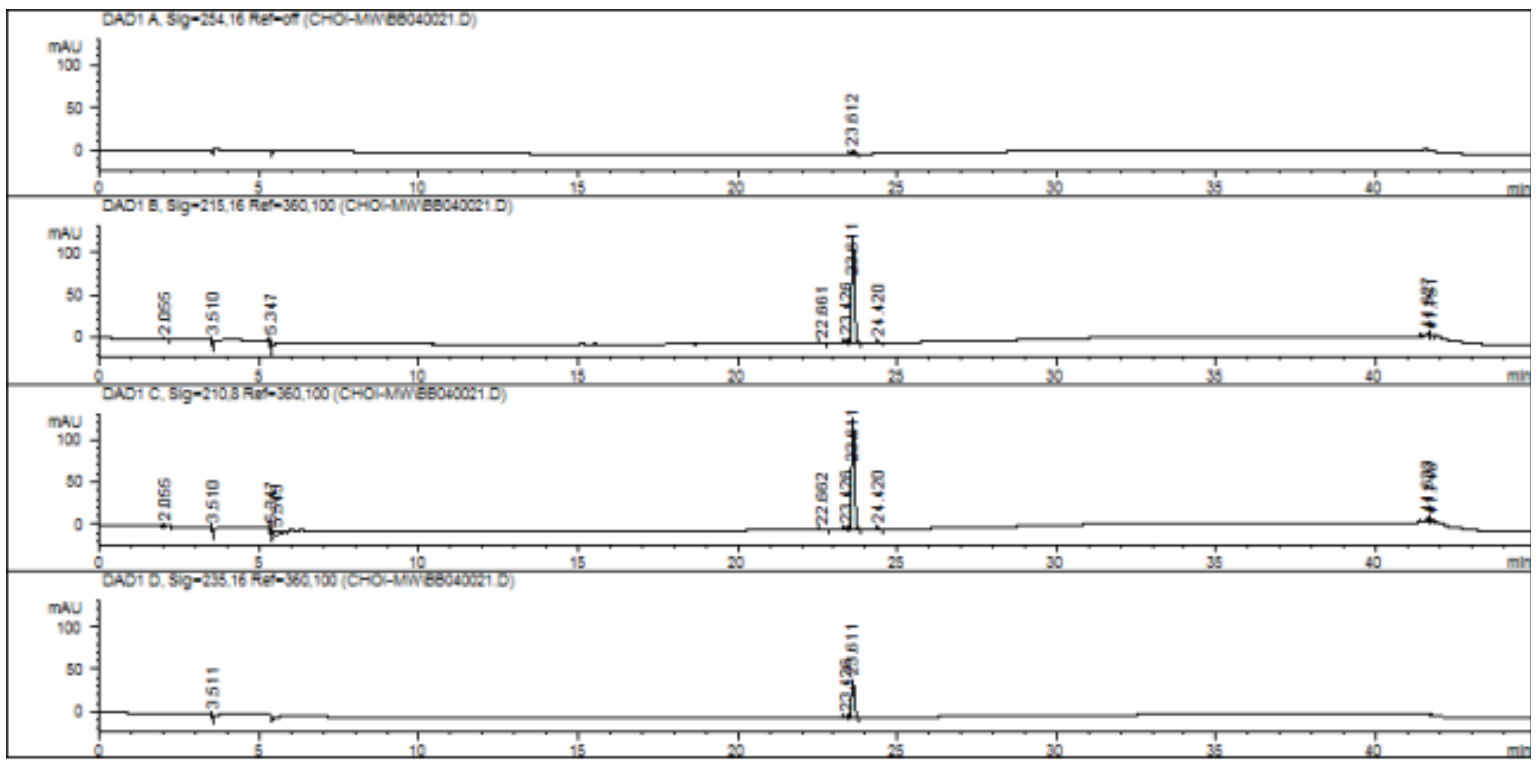

Fig. 3. Typical HPLC chromatograms of the reference bakkenolide B $(100 \mu \mathrm{g} / \mathrm{ml})$. Analyses were carried out on a Luna $\mathrm{C}_{18}$ column with a mobile phase gradient of acetonitrile - water $(0$ to 100) for $35 \mathrm{~min}$. The injection volume was $10 \mu \mathrm{l}$ sample. The column temperature was kept constant at 30, and the mobile phase flow rate was $0.4 \mathrm{ml} \mathrm{min}^{-1}$ with UV detection at 210, 215, 235, $254 \mathrm{~nm}$ and $360 \mathrm{~nm}$.

Table 2. Regression data, LODs and LOQs for the bakkenolide B by HPLC

\begin{tabular}{cccccc}
\hline Wavelength $(\mathrm{nm})$ & Calibration curve & $\mathrm{r}^{2}$ & Linear range $(\mu \mathrm{g})$ & LOD $^{\mathrm{y}}(\mu \mathrm{g})$ & LOQ $^{\mathrm{x}}(\mu \mathrm{g})$ \\
\hline $215 \mathrm{~nm}$ & $\mathrm{y}=7.841 x-6.262$ & 0.9999 & $25-500$ & 1.049 & 3.379 \\
$254 \mathrm{~nm}$ & $\mathrm{y}=0.226 \mathrm{x}-0.475$ & 0.9999 & $25-500$ & 2.259 & 6.844 \\
\hline
\end{tabular}

${ }^{\mathrm{z}} \mathrm{X}$ is the peak area in UV chromatograms, $\mathrm{Y}$ is the compound amount injected

${ }^{\mathrm{y}} \mathrm{LOD}$ refers to the limits of detection

${ }^{x} \mathrm{LOQ}$ refers to the limits of quantification 
Table 3. Precision of the bakkelolide $B(n=6)$

\begin{tabular}{ccccc}
\hline \multirow{2}{*}{ Replication } & $\begin{array}{c}\text { Retention } \\
\text { time (min) }\end{array}$ & \multicolumn{2}{c}{ Peak area } & Concentration \\
\cline { 3 - 4 } & $215 \mathrm{~nm}$ & $254 \mathrm{~nm}$ & $(\mu \mathrm{g} / \mathrm{ml})$ \\
\hline 1 & 23.611 & 745.2 & 22.5 & 100 \\
2 & 23.612 & 742.1 & 22.2 & 100 \\
3 & 23.611 & 739.7 & 22.1 & 100 \\
4 & 23.610 & 739.2 & 22.1 & 100 \\
5 & 23.610 & 738.9 & 22.1 & 100 \\
6 & 23.591 & 740.7 & 22.2 & 100 \\
\hline Mean & 23.608 & 740.967 & 22.200 & \\
SD & 0.0081 & 2.3779 & 0.1549 & \\
$\%$ RSD & 0.0344 & 0.3209 & 0.6978 & \\
\hline
\end{tabular}

$\operatorname{RSD}(\%)=(\mathrm{SD} /$ mean $) \times 100$

Table 4. Recovery of the bakkenolide B of $P$. japonicus in leaves $(\mathrm{n}=3)$.

\begin{tabular}{rrrrrrr}
\hline \multirow{2}{*}{$\begin{array}{c}\text { Spike } \\
(\mu \mathrm{g} / \mathrm{ml})\end{array}$} & \multicolumn{2}{c}{ Intra-day $(\mathrm{n}=6)$} & & \multicolumn{2}{c}{ Inter-day } \\
\cline { 2 - 3 } \cline { 5 - 6 } & $\begin{array}{c}\text { Found } \\
\text { mean } \pm \text { SD }\end{array}$ & $\begin{array}{c}\text { RSD }(\%) \\
(\mathrm{n}=3)\end{array}$ & & $\begin{array}{c}\text { Found } \\
\text { mean } \pm \text { SD }\end{array}$ & $\begin{array}{c}\text { RSD }(\%) \\
(\mathrm{n}=3)\end{array}$ \\
\hline 50 & $50.11 \pm 0.44$ & 0.99 & & $44.44 \pm 0.26$ & 1.00 \\
100 & $104.30 \pm 1.28$ & 1.01 & & $100.70 \pm 1.42$ & 0.99 \\
200 & $211.81 \pm 0.88$ & 1.00 & & $211.74 \pm 4.61$ & 0.98 \\
\hline
\end{tabular}

Recovery $=$ Peak area of sample/peak area of control.

wavelength variations were less than $1 \%$ for bakkenolide $\mathrm{B}$. Besides, validation studies of this method proved that this assay has a good reproducibility with RSD also less than $1 \%$ for the bakkenolide $\mathrm{B}$.

The developed analytical method has good accuracy with the overall recovery from 97.34 to $107.45 \%$ at intra-day and 100.22 to $105.91 \%$ at inter-day for 3 different spike levels (Table 4). The recovery efficiencies of RSD (\%) for bakkenolide B at three different concentrations (50, 100 and $200 \mu \mathrm{g} /$ $\mathrm{ml}$ ) were $0.99-1.01 \%$. Therefore, the method is precise, accurate and sensitive enough for bakkenolide B quantitative evaluation in $P$. japonicus.

\section{Quantitative determination of bakkenolide $B$ in $P$. japonicus}

This newly developed HPLC assay method was subsequently applied to bakkenolide B determination for different season and parts of $P$. japonicus. The content of bakkenolide $\mathrm{B}$ was determined by the corresponding regression equation. The content of bakkenolide B in leaf was higher than in other parts and samples collected earlier in seasonal changes.

\section{Discussion}

Bakkenolide derivatives is one of the most important medical constituent of Petasites and its distribution is as significant as the differences observed with petasin derivatives. HPLC method for effective determination of bakkenolide B contents of $P$. japonicus was developed. The chromatogram of optimized separation on the column Luna $C_{18} 100 \mathrm{~A}$ column $(150 \times 3.0 \mathrm{~mm})$ as gradient phase gave the most sufficient results with mobile phases: acetonitrile (A) and water at zero to $100 \%$ for $35 \mathrm{~min}$ (Fig. 3, Table 2). Avula et al. [2] developed two UPLC-UV and HPLC - ToF - MS methods for the analysis of major sesquiterpene constituents including petasin, isopetasin, S-petasin and $8 \beta$-H-eremophilanolide from roots of $P$. hybridus and dietary supplements containing P. hybridus extracts. Wang et al. [19] carried out the analyses on Agilent-ODS $\mathrm{C}_{18}$ column with mobile phase consisting of tetrahydrofuran - acetonitrile - water (28:12:60, $\mathrm{v} / \mathrm{v} / \mathrm{v}$ ) to estimate simultaneous determination of four major active bakkenolides in $P$. tricholobus. The column temperature was at $55^{\circ} \mathrm{C}$ and UV detections were at $265 \mathrm{~nm}$ between 0 and $15 \mathrm{~min}$ and at $235 \mathrm{~nm}$ between 15 and $32 \mathrm{~min}$.

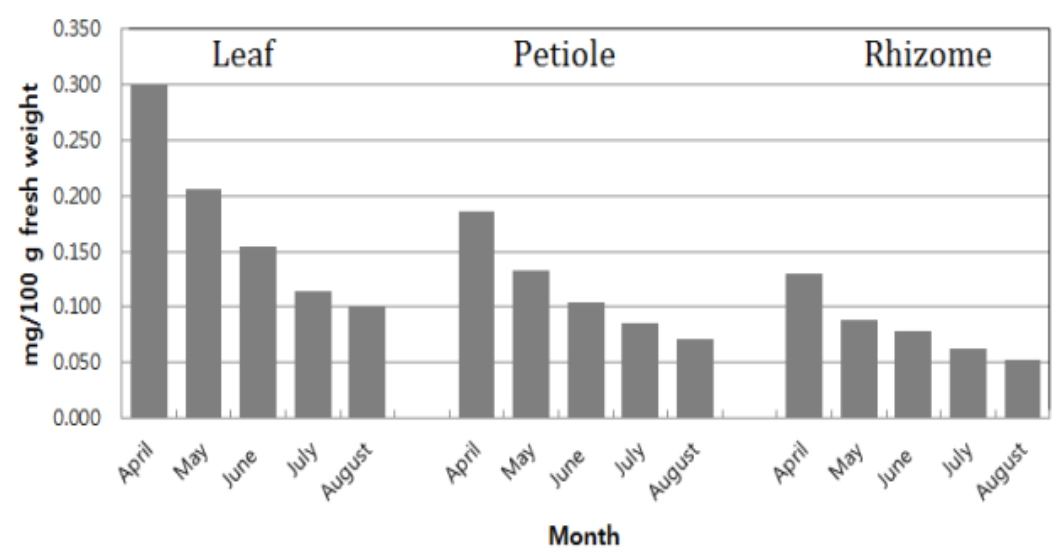

Fig. 4. Contents of bakkenolide B from different plant parts. Leaves, petioles and rhizomes were collected from April to August in 2013. Analyses were carried out on a Luna $\mathrm{C}_{18}$ column with a mobile phase gradient of acetonitrile - water $(0$ to 100) for $35 \mathrm{~min}$. The injection volume was $10 \mu \mathrm{l}$ sample. The column temperature was kept constant at $30^{\circ} \mathrm{C}$, and the mobile phase flow rate was $0.4 \mathrm{ml} \mathrm{min}^{-1}$ with UV detection at $254 \mathrm{~nm}$. 
These literatures [19] and our results provide useful analysis method for determination of bekkenolide B. Wildi et al. [20] conducted the analyses of petasin distribution in rhizomes and leaves of the plant. The mean petasin content of populations ranged from 7.4 to $15.3 \mathrm{mg} / \mathrm{g}$ dry weight in rhizomes and from 3.3 to $11.4 \mathrm{mg} / \mathrm{g}$ dry weight in leaves of $P$. hybridus. The concentration of bakkenolides was found to be significantly higher in rhizomes than in flowers and leaves of $P$. tricholobus [19]. Chizzola et al. [4] analyzed the essential oil content of leaves, roots and flower stems of $P$. japonicus with GC and GC-MS. According to these results, contents of bakkenolode B and other bioactive compounds were different with plant parts, but bakkenolide B was generally found in younger metabolically active parts of leaves and it was also lower content in petioles and rhizomes (Fig. 4). The seasonal variation of bakkenolide B content in leaves, petioles and rhizomes decreased with later collection date. In this sense, the leaves are more favorable for harvesting with much higher bakkenolide B concentrations (Fig. 4) and petasin rich extracts $[8,20]$ since the changes in petasin concentrations between leaves and rhizomes of the plant are not tremendous [3]. In conclusion, a simple, accurate and rapid HPLC method was developed for bakkenolide B in $P$. japanicus. The HPLC assay is sensitive, reproducible and has been fully validated. The results indicate that samples from different season and parts of the plant show a specific HPLC chromatogram. This method can be used to determine the content of bakkenolide B from other Petasites species plants.

\section{Acknowledgement}

This work was supported by a 2-Year Research Grant of Pusan National University.

\section{References}

1. Abe, N., Onoda, R., Shirahata, K., Kato, T., Woods, M. C., Kitahara, Y., Ro, K. and Kurihara, T. 1968. The structures of bakkenolides-B, $-\mathrm{C}$ and $-\mathrm{D}$ as determined by the use of a nuclear overhauser effect. Tetrahedron Lett 9, 1993-1997.

2. Avula, B., Wang, Y. H., Wang, M., Smillie, T. J. and Khan, I. A. 2012. Simultaneous determination of sesquiterpenes and pyrrolizidine alkaloids from the rhizomes of Petasites hybridus (L.) G.M. et Sch. and dietary supplements using UPLC-UV and HPLC - ToF - MS methods. J Pharm Biomed Anal 70, 53-63.

3. Aydın, A. A., Zerbes, V., Parlar, H. and Letzel, T. 2013. The medical plant butterbur (Petasites): Analytical and physiological (re)view. J Pharm Biomed Anal 75, 220-229.

4. Chizzola, R., Ozelsberger, B. and Langer, T. 2000. Variability in chemical constituents in Petasites hybridus from Austria. Biochem Syst Ecol 28, 421-432.

5. Dawson, T. M. and Dawson, V. L. 2003. Molecular pathways of neurodegeneration in Parkinson's disease. Science 302, 819-822.

6. Dong, X. W., Li, R. J., Gao, X. and Row, K. H. 2010. Bakkenolides from Petasites tatewakianus. Fitoterapia 8, 153156.

7. Jung, Y. S., Lee, S. K., Ok, C. Y., Cho, E. J., Park, J. S., Choi, Y. W. and Bae, Y. S. 2013. Role of CXCR2 on the immune modulating activity of a-iso-cubebenol a natural compound isolated from the Schisandra chinensis fruit. Biochem Biophys Res Commun 431, 433-436.

8. Langer, T., Mostl, E., Chizzola, R. and Gutleb, R. 1996. A competitive enzyme immunoassay for the pyrrolizidine alkaloids of the senecionine type. Planta Med 62, 267-271.

9. Lee, K. P., Kang, S., Park, S. J. Choi, Y. W., Lee, Y. G. and Im, D. S. 2013. Anti-allergic and anti-inflammatory effects of bakkenolide B isolated from Petasites japonicus leaves. $J$ Ethnopharmcol 148, 890-894.

10. Nanjing University of Chinese Medicine. 2006. Dictionary of Chinese materia medica, 2nd (eds.), pp. 3490-3491, Shanghai: Shanghai Scientific and Technological Press.

11. Naya, K., Kawai, M., Naito, M. and Kasai, T. 1972. The structures of eremofukinone, 9-acetoxyfukinanolide, and S-japonin from Petasites japonicus maxim. Chem Let 1972, 241-244.

12. Park, S. Y., Park, S. J., Park, N. J., Joo, W. H., Lee, S. J. and Choi, Y. W. 2013. a-Iso-cubebene exerts neuroprotective effects in amyloid beta stimulated microglia activation. Neurosci Lett 555, 143-148.

13. Park, S. Y., Park, S. J., Park, T. G., Rajasekar, S., Lee, S. J. and Choi, Y. W. 2013. Schizandrin C exerts anti-neuroinflammatory effects by upregulating phase II detoxifying/antioxidant enzymes in microglia. Int Immunopharmacol 17, 415-426.

14. Shimoda, H., Tanaka, J., Yamada, E., Morikawa, T., Kasajima, N. and Yoshikawa, M. 2006. Anti type I allergic property of Japanese butterbur extract and its mast cell degranulation inhibitory ingredients. I Agric Food Chem 54, 2915-2920.

15. Shirahata, K., Kato, T., Kitahara, Y. and Abe, N. 1969. Constituents of Petasites. IV. Bakkenolide-A, a sesquiterpene of novel carbon skeleton. Tetrahedron 25, 3179-3191.

16. Sok, D. E., Oh, S. H., Kim, Y. B., Kang, H. G. and Kim, M. R. 2006. Neuroprotection by extract of Petasites japonicus leaves, a traditional vegetable, against oxidative stress in brain of mice challenged with kainic acid. Eur J Nutr 45, 61-69.

17. Tori, M., Kawahara, M. and Sono, M. 1997b. Novel epoxyeremophilanolides, eremopetasitenins A1, A2, B1, and B2, from Petasites japonicus. Tetrahedron Let 38, 1965-1968.

18. Torres, P., Ayala, J., Grande, C., Macias, M. and Grande, M. 1998. Furanoeremophilanes and a bakkenolide from 
Senecio auricula var. major. Phytochemistry 47, 57-61.

19. Wang, Y. L., Guo, M. and Wang, Y. 2009. Quality evaluation of Petasites tricholobus through simultaneous determination of four bioactive bakkenolides by LC. Chromatographia 70, 1367-1371.

20. Wildi, E., Langer, T., Schaffner W. and Buter, K. B. 1998. Quantitative analysis of petasin and pyrrolizidine alkaloids in leaves and rhizomes of in situ grown Petasites hybridus plants. Planta Med 64, 264-267.

21. Wu, T. S., Kao, M. S., Wu, P. L., Lin, F. W., Shi, L. S., Liou, M. J. and Li, C. Y. 1999. The bakkenolides from the root of Petasites formosanus and their cytotoxicity. Chem Pharm
Bull 47, 375-382.

22. Yaoita, Y. and Kikuchi, M. 1994. Constituents of the rhizomes of Petasites japonicus Maxim. IV. Structures of six new eremophilenolides from the rhizomes of Petasites japonicus Maxim. Chem Pharm Bul 42, 1944-1947.

23. Yaoita, Y. and Kikuchi, M. 1996a. seco-Eremophilane derivatives from rhizomes of Petasites japonicus. Phytochemistry 42, 751-755.

24. Yaoita, Y. and Kikuchi, M. 1996b. Structures of new dinor-eremophilane derivatives and new eremophilenolides from the rhizomes of Petasites japonicus Maxim. Chem Pharm Bul 44, 1731-1735.

\title{
초록 : 머위로부터 Bakkenolide B의 순수분리, HPLC분석 방법 및 채취 시기별 함량 분석
}

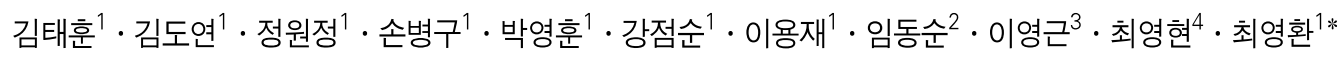

( ${ }^{1}$ 부산대학교 원예생명과학과, ${ }^{2}$ 부산대학교 약학과, ${ }^{3}$ 부산대학교 식품공학과, ${ }^{4}$ 동의대학교 한의과대학 생화학교실)

머위(Peatasites japonicus)의 잎으로부터 생리활성물질을 탐색하여 항천식 효과가 있는 물질로 알려진 bakenolide $\mathrm{B}$ 를 순수분리하였으며, 1D-NMR, 2D-NMR 및 GC-MS spectrum 데이터를 이용하여 구조를 동정하였다. 머위의 잎, 엽병 및 근경 등의 채취시기별 bakkenolide B의 함량을 평가하기 위하여 HPLC 분석 방법을 확립하였다. Bakkenolide B의 민감도는 $210 \mathrm{~nm}$ 와 $215 \mathrm{~nm}$ 의 파장에서 $254 \mathrm{~nm}, 235 \mathrm{~nm}$ 및 $265 \mathrm{~nm}$ 보다 높았으며, 분석을 위한 회귀 직선식은 $\mathrm{y}=7.841-6.262$ (파장 $215 \mathrm{~nm}$ )로서 상관값 $\left(\mathrm{r}^{2}\right)$ 이 0.999 이상으로서 유의성이 매우 높았다. 검출한계(LOD)는 1.05 , 정량한계 (LOQ)는 3.38이었다. 회수율은 3종류의 농도값에 대하여 98.6 에서 103.1\%로서 매우 높았다. 이러한 결과들로 미루어 볼 때 머위에서 bakkenolide B의 함량은 HPLC 분석방법으로서 가능한 것으로 증명되었다. 따라서 식물체의 부위 즉 잎, 엽병 및 근경에서의 bakkenolide $\mathrm{B}$ 의 함량을 측정한 결과, 잎에서 가장 높았고, 다음은 엽병이었으며, 근경에서 함량이 가장 낮았다. 3 월 초부터 8 월 초까지 1 개월 간격으로 식물체의 부위별 bakkenolide B의 함량을 조사한 결과, 3 월부터 8 월까지 채취시기가 지연될수록 감소하는 경향이었다. 따라서 HPLC를 이용한 Petasites species의 bakkenolides 분석은 단순하고, 급속하게 분석할 수 있는 방법으로 확인되었다. 